\title{
Imidacloprid Induces Oxidative Stress and Genotoxicity in Nile Tilapia: The Role of Ascorbic Acid Combined Exposure
}

Islam M. El-Garawani ( $\nabla$ dr.garawani@science.menofia.edu.eg )

Menoufia University

Elsayed A. Khallaf

Menoufia University

Alaa A. Alne-na-ei

Menoufia University

Rehab G. Elgendy

Menoufia University

Gaber A.M. Mersal

Taif University

Hesham R. El-Seedi

Uppsala University

\section{Research Article}

Keywords: Imidacloprid, Ascorbic acid, oxidative stress, genotoxicity, Oreochromis niloticus.

Posted Date: May 24th, 2021

DOl: https://doi.org/10.21203/rs.3.rs-528212/v1

License: (1) This work is licensed under a Creative Commons Attribution 4.0 International License.

Read Full License

Version of Record: A version of this preprint was published at Scientific Reports on July 19th, 2021. See the published version at https://doi.org/10.1038/s41598-021-94020-y. 


\section{Abstract}

Imidacloprid (Imid), a systemic neonicotinoid insecticide, is broadly used worldwide. It is reported to contaminate aquatic systems. This study was proposed to evaluate oxidative stress and genotoxicity of Imid on Nile tilapia (Oreochromis niloticus) and the protective effect of ascorbic acid (Asc). O. niloticus juveniles $(30.4 \pm 9.3 \mathrm{~g}, 11.9 \pm 1.3 \mathrm{~cm}$ ) were divided into six groups ( $\mathrm{n}=10 /$ replicate). For 21 days, two groups were exposed to sub-lethal concentrations of Imid (8.75 ppm, 1/20 of 72h-LC ${ }_{50} \& 17.5$ ppm, 1/10 of $\left.72 \mathrm{~h}-\mathrm{LC}_{50}\right)$; other two groups were exposed to Asc $(50 \mathrm{ppm})$ in combination with Imid (8.75 \& 17.5 ppm); one group was exposed to Asc (50 ppm) in addition to a group of unexposed fish which served as controls. Oxidative stress was assessed in the liver where the level of enzymatic activities including superoxide dismutase (SOD), catalase (CAT) and glutathione peroxidase (GPX) in addition to mRNA transcripts and, Lipid peroxidation (LPO) were evaluated. Moreover, mitotic index (MI) and comet assay were performed, in addition to the erythrocytic micronucleus (MN), and nuclear abnormalities (NA) were observed to assess genotoxicity in fish. Imid exposure induced significant ( $\mathrm{p} \otimes 0.05)$ changes in the antioxidant profile of the juveniles' liver by increasing the activities and gene expression of SOD, CAT and GPX as well as elevating the levels of LPO. DNA strand breaks in gill cells, erythrocytes and hepatocytes along with erythrocytic MN and NA were also significantly elevated in Imid-exposed groups. MI showed a significant ( $p \otimes 0.05)$ decrease associated with Imid exposure. Asc administration induced a significant amelioration towards the Imid toxicity $(8.75 \& 17.5 \mathrm{ppm})$. A significant protective potency against the genotoxic effects of Imid was evidenced in Asc co-treated groups. Collectively, results highlight the importance of Asc as a protective agent against Imid-induced oxidative stress and genotoxicity in $O$. niloticus juveniles.

\section{Introduction}

The aquatic environment is continually contaminated with agricultural chemicals, pesticides and urban activities. Aquatic pollutions affect the health and survival status of the organisms ${ }^{1,2}$.. In most tropical and subtropical regions, tilapia is introduced for fish farms and constitute an important dietary item for human consumption. Thus, tilapia became the most common freshwater fishes in aquaculture worldwide 3,4 .

Neonicotinoids are one of the most used synthetic groups of insecticides owned to their high effectiveness against a wide range of insects. They are replacing older classes of insecticides such as carbamate and organophosphate worldwide because they are non-volatile, and easily soluble in water 5,6 . Neonicotinoids are widely contaminating the environment due to their absorption by the seeds, and then their direct release through leaching, drainage, run-off, or snowmelt ${ }^{7,8}$. Imidacloprid (Imid) was the first neonicotinoid introduced in 1991 and since has been one of the key ingredients of several pest control programs ${ }^{9,10}$. Xenobiotics or toxic chemicals including Imid may affect the endogenous and exogenous reactive oxygen species (ROS) balance and can subsequently suppress the antioxidant defenses or induce macromolecules oxidative damage in many organisms ${ }^{11-13}$. 
Imid causes cellular stress when consumed by fresh water Cyprinus carpio for 30 days leading to the decline of the population size in its natural habitat ${ }^{2}$. Its toxicity in Oncorhynchus mykiss and Danio rerio ${ }^{14}$, Cyprinus carpio ${ }^{2}$ and 0 . niloticus ${ }^{4}$ was reported. In carp fish, it induced severe inflammation, oxidative stress and histopathological lesions in the gills, liver, and brain ${ }^{15}$. Australoheros facetus, exposed acutely to environmentally relevant concentrations of Imid ( 1 to $1000 \mu \mathrm{g} / \mathrm{L}$ ), showed oxidative damage affecting the genetic integrity of the fish ${ }^{16}$. Changes of the cellular detoxification and oxidative status of Corbicula fluminea were also reported ${ }^{17}$. Fish leukogram was reported to be affected due to sub-lethal concentrations of Imid (140 and $280 \mathrm{mg} / \mathrm{L}$ of imidacloprid for $96 \mathrm{~h}$ ) ${ }^{4}$.

Biological structures and functions can be early disturbed by DNA damage and micronucleus (MN) formation which could lead to a genotoxicity eventually associated with carcinogenicity and reproductive disorders ${ }^{18-20}$. Using the comet assay, a higher level of DNA damage was reported in fishes due to genotoxicity ${ }^{21-23}$. In Prochilodus lineatus fish, MN and DNA damage were evidenced in the erythrocytes as a result of Imid exposure ${ }^{6,24}$. Vitamin C, chemically known as ascorbic acid (Asc), is well known for its strong antioxidant potency ${ }^{25-27}$. It is a good reducing agent and inhibits lipid peroxidation ${ }^{28}$, And even in small doses, its effectiveness for redox recycling was proved ${ }^{29}$. ROS conversion to harmless metabolites in addition to the protection and restoration of normal cellular metabolism and functions are mediated by endogenous enzymatic and non-enzymatic antioxidants ${ }^{30}$. Previously, it was reported that Asc is able to scavenge free radicals in pesticides-induced oxidative stress in various fish species ${ }^{12,31-}$ 33. In earlier studies, beneficial effects of Asc on adult Oncorhynchus mykiss were proven ${ }^{34}$

Thus, the purpose of the current study was to investigate the potential protective effect of Asc to overcome the hazards of insecticide applications in the surrounding environment. It was crucial to investigate the change of the oxidative markers including SOD, CAT, GPX and LPO in addition to evaluating the associated genotoxicity. $O$. niloticus is considered a rich dietary source and one main aspect of the fishery future, thus concluding the Imid-induced oxidative stress and genotoxicity in its juveniles and the possible preventive strategies such as Asc administration in the aquaculture, is warranted. To the best of our knowledge, this is the first report focusing on this point on 0 . niloticus.

\section{Results}

\section{Dose assessment in water}

In order to assess the degradation of the tested compounds in the experimental water, HPLC was performed for Imid and Asc. Results after $24 \mathrm{~h}$ of compounds' application revealed that the degradation of Asc in water was approximately $30 \%$. However, Imid has higher stability in water with a degradation around $9 \%$.

\section{Lethal concentration, general conditions and health}


Imid concentrations of $17.5 \mathrm{ppm}\left(1 / 10\right.$ of $\left.\mathrm{LC}_{50}\right)$ and $8.75 \mathrm{ppm}\left(1 / 20\right.$ of $\left.\mathrm{LC}_{50}\right)$ used in this study were chosen based on the determined lethal concentration of Imid in 0 . niloticus juveniles (175.32 ppm) after $72 \mathrm{~h}$ (Fig. 1). During the experiment, there was no mortality in the studied groups. The characteristics (chemical and physical) of the water over the experimental period remained stable including Imid and Asc concentrations. Behavioral and morphological observations were detected in Imid-treated groups (8.75 \& $17.5 \mathrm{ppm}$ ) such as darkness in fish color, erected fins and sluggish movement.

\section{Antioxidant markers in fish livers}

In order to assess the oxidative stress in fish, the enzymatic activities of SOD, CAT and GPX were investigated in liver tissues (Fig. 2). Results revealed that SOD, CAT and GPX were elevated significantly $(\mathrm{P}<0.05)$ by 52.5, 26.6 \& 106.3\% respectively, in $8.75 \mathrm{ppm}$ of Imid-exposed group. While higher dose $(17.5 \mathrm{ppm})$ increased the activities by 20.6, 58.8 \& 19.5\% respectively, with a significant differences except for GPX activities that was non-significant, when compared with control. Moreover, LPO levels were significantly elevated by 18, 42.8\% among low and high concentrations of Imid. Asc co-treatments showed a significant decrease in SOD, CAT and GPX levels by $11.5 \& 24.4,5 \%$ in low dose and by 13.9 , 38.4 \& 32.5\% respectively, in higher dose of Imid co-treated group when compared with Imid-exposed group. The activities of SOD in higher co-treated group and GPX in lower one showed non-significant $(\mathrm{P}<$ 0.05 ) elevations, however, other co-treated groups showed a significant ameliorative effect of Asc towards the oxidative stress induced by Imid. Further, LPO levels were significantly $(P<0.05)$ decreased by 20.9, 32.6\% in low and high dose of Imid co-treated groups respectively, compared to Imid-exposed groups. Asc treatment showed a significant decrease by 21.6\% compared to control.

\section{Relative gene expression of SOD, CAT and GPX}

Antioxidant genes expression for SOD, CAT and GPX were investigated in liver tissues (Fig. 3). A significant ( $p \otimes 0.05$ ) up-regulation of relative mRNA by $\sim 10.6,0.5 \& 3$ fold respectively were observed in $8.75 \mathrm{ppm}$ of Imid-exposed group. However, $17.5 \mathrm{ppm}$ Imid-exposed fish showed a significant higher upregulation than the low Imid concentration by $\sim 25 \& 1.5$ for SOD and CAT respectively. In contrast, GPX showed a non-significant elevation by $\sim 0.33$ folds. Relative to Imid-exposed group, Asc co-treatments showed a protective effects by down-regulating the SOD, CAT and GPX mRNA expression by 10.2, 0.8 \& 2.6 folds in low dose and by 24.6, $1.5 \& 0.04$ folds in higher dose of Imid co-treated respectively. All protective effects were significant ( $\mathrm{p} \otimes 0.05$ ) except GPX gene expression which showed a non-significant down-regulation in higher dose.

\section{Genotoxic analysis}

\section{DNA strand breaks}

DNA strand breaks (comet assay) was performed to assess the effect of Imid exposure and the protective role of Asc on gill cells, erythrocytes and hepatocytes of tilapia juveniles (Fig. 4). Fish exposed to Imid $(8.75 \mathrm{ppm})$ showed a significant ( $\mathrm{p} \otimes 0.05)$ increase in DNA damage of gills (Fig. 4-A\&D), erythrocytes 
(Fig. 4-B\&E) and liver cells (Fig. 4-C\&F) by about 259.1, 147.9 \& 130.5\% respectively. However, the higher dose (17.5 ppm) significantly elevated the damage by approximately 423.5, $319.4 \& 224.5 \%$ respectively, compared to control.

In contrast, a significant ( $\mathrm{p} \otimes 0.05$ ) protective impact of Asc was evidenced by decreasing DNA damage induced by 8.75 and $17.5 \mathrm{ppm}$ of Imid exposure. The records of lower dose were approximately 66.7, 51.3 \& $53.5 \%$ in gill cells, erythrocytes and hepatocytes, respectively. Additionally, at the higher Imid dose (17.5 ppm) co-treatment, Asc was significantly decreasing the DNA damage by about $74.2,54.5 \& 52.9 \%$, respectively.

\section{Evidences of micronuclei (MN) and erythrocytic nuclear abnormalities (ENA)}

The frequencies of MN and ENA were assessed in the treated and control fish to monitor the genotoxic effect of Imid exposure ( $8.75 \& 17.5 \mathrm{ppm}$ ) and the ameliorative effect of Asc (Fig. 5). Fish exposed to Imid showed a significant ( $\mathrm{p} \otimes 0.05$ ) increase in MN and ENA by 214.8 \& 676.6\% in Imid-exposed group to lower dose and in parallel, the higher one by $\sim 879 \& 248.2 \%$ respectively. In respect to the Imidexposed groups, Asc co-treatments showed a significant ( $\mathrm{p} \otimes 0.05$ ) decrease in MN and ENA by $~ 74.3$ \& $52.7 \%$ at the low dose and by $\sim 88.6 \& 70.6 \%$ at the higher one, respectively. Similarly, Asc treatment showed a significant ( $\mathrm{p} \otimes 0.05$ ) decrease in ENA by 86.3\% compared to control.

\section{Mitotic index}

Chromosomal preparation was performed in order to assess the mitotic index (MI) in control and treated fish kidneys. MI showed a significant ( $\mathrm{p} \nabla 0.05$ ) decrease by 50.3 \& 60.9\% in 8.75 and $17.5 \mathrm{ppm}$ doses, respectively in 0 . niloticus after exposure to Imid. On the other hand, MI showed a significant ( $\mathrm{p} \otimes 0.05$ ) increase in Asc co-treatment groups as observed by 24.2 \& 37.9\% in low and high doses respectively, compared to their Imid-exposed groups. While, Asc-treated group alone showed a significant elevation in Ml by 19.2\% when compared to control group (Fig. 6).

\section{Discussion}

The antioxidative system plays an crucial role in repelling exogenous pollution, and other stimuli that induce the production of the superoxide anion, the intracellular parental form of reactive oxygen species (ROS), which is a highly active molecule and thereby causing various damages to cells and organisms ${ }^{35}$. Superoxide anion radicals can be catalyzed by superoxide dismutase (SOD) to form oxygen and hydrogen peroxide $\left(\mathrm{H}_{2} \mathrm{O}_{2}\right)$. The decompositon of $\mathrm{H}_{2} \mathrm{O}_{2}$ into molecular oxygen and water is performed by catalase (CAT) activities, preventing the toxicity of $\mathrm{H}_{2} \mathrm{O}_{2}$ and the oxidative stress cascade ${ }^{36}$. SOD and CAT are considered the primary antioxidant enzymes that contribute to the balance of free radicals in organisms and their activation is thus needed ${ }^{35}$. The activity of CAT was significantly enhanced in the fish digestive glands and gills following 30 days of Imid exposure ${ }^{17}$. In agreement, in this research, the SOD, CAT and GPX activities in the liver tissues were significantly increased in fishes receiving Imid 
treatments, which may be due to the production of ROS ${ }^{35}$. GPX like CAT and SOD are considered as an oxidative stress indicator and has a vital role in the protection by normalizing the ROS levels ${ }^{37-40}$. Similarly to the finding of this study, Vieira et al. ${ }^{6}$ reported that, in gills, lower concentration of Imid caused a significant elevations in SOD and GPX activities which were subsequently declined in correspondence to the increase of Imid concentration. This may be due to the over accumulation of free radicals that, exceeded the antioxidant defense systems ability and the impact of Imid on the antioxidant balance, these finding are in agreement with Saddick et al. ${ }^{41}$.

Levels of LPO is correlated to the antioxidant status ${ }^{42,43}$ and reflects the loss of membrane integrity ${ }^{11}$ prior to the cellular damage. The alterations in the antioxidant enzymes (SOD and CAT) in the current study suggest a state of oxidative stress accompanied by an elevation of ROS levels, and confirmed by the detection of high LPO levels in the liver of $O$. niloticus exposed to Imid. The activities and mRNA transcripts levels of SOD, CAT and GPX were significantly increased in Imid-exposed groups. Equally important, the elevation of CAT and GPX is considered as oxidant stress indicator in tilapias ${ }^{43}$. The differences between SOD activity and transcripts could be explained by a responses delay at different levels, or by the impact of toxicants on transcriptional or translational mechanisms ${ }^{44,45}$.

The disturbance of biological structures and functions could be correlated to DNA damage leading to genotoxicity ${ }^{18}$. DNA damage in hepatocytes, erythrocytes and gill cells was reported in fish exposed to Imid ${ }^{24}$. This may be due to the formation of $\mathrm{H}_{2} \mathrm{O}_{2}$ which is difficult to be eliminated leading to oxidative DNA damage specially in the diminished antioxidant enzymatic activities ${ }^{36,46,47}$. The damage was explained by the entrance of pyrethroids to the nucleus through cell membranes and its interaction with DNA leading to DNA unwinding and genetic material damages ${ }^{48}$. Moreover, DNA damage may be occurred due to interacting with generated oxygen radicals and the formation of DNA-protein or DNA-DNA crosslinks ${ }^{49}$. Our results revealed that fish exposed to Imid for 21 days exhibited DNA damage that was increased in gill cells, hepatocytes and erythrocytes.

In the present study, MN and ENA showed a significant increase in Imid-exposed fish suggesting dysfunction of mitotic spindle and/or breaks of DNA strands of the hematopoietic tissues ${ }^{50,51}$. Our results are supported by previous reports where MN and ENA were seen earlier in fish following the administration of Imid ${ }^{16,24}$. and the process was owned to the fact that Imid can affect the erythrocytic nuclear membrane leading to the DNA fragmentation, MN and ENA formation in a time and dose dependency ${ }^{46}$. The current results are in agreement with Iturburu et al. ${ }^{16}$. The results of mitotic index, known as a cell division marker ${ }^{52}$, showed a decrease in fish exposed to sub-lethal concentrations of Imid. The in vitro aneunogenic effects may lead to cellular imbalances and this phenomenon was documented earlier for Imid exposure ${ }^{53}$. The decreased $\mathrm{MI}$ in rats exposed to malathion pesticide were reported ${ }^{52}$. As observed in several animal models, the genotoxicity is suggested to be mediated by the generation of oxidative stress associated with diminished acetylcholinesterase and GPX activities in addition to elevated SOD and CAT activities ${ }^{54-58}$. 
Asc, a water-soluble vitamin ${ }^{59}$, is a non-enzymatic antioxidant agents acting on both extracellular and intracellular fluids and able to neutralize many radicals ${ }^{60}$. In this study, Asc co-treatments decreased the antioxidant enzymes and LPO in liver leading to ameliorative effect against Imid-induced oxidative stress. At the level of genotoxicity, Asc co-treatments decreased DNA damage, MN and ENA, however, the MI was elevated. The impact of Asc is owned to the decreased ROS and LPO ${ }^{61}$ which improved the antioxidant status either by radical scavenging or elevating the antioxidant defense system leading to alleviation of oxidative stress that affect DNA and other macromolecules in fish ${ }^{51,54}$. Several studies indicated that Asc is an effective protective tool against the tissue damage and toxicity caused in various organisms by environmental pollutants such as toxicants, pesticides and insecticides ${ }^{33,62,63}$. Due to the production of free radicals or ROS and peroxidation of cell membrane lipids, these chemicals contribute to cell, tissue or even animal death. Asc either acts as a free radical scavenger ${ }^{64}$ and also increases the innate immunity of fish 27,65 in addition to preventing the mitochondrial oxidative damage which consequently reduces the DNA and other macromolecules damage ${ }^{66-68}$.

In conclusion, the current study provides a new insight on the protective effect of ascorbic acid supplementation against the oxidative stress and associated genotoxic damage resulted by imidacloprid exposure. As the best of our knowledge, this is the first report linked the Imid exposure with Ascameliorated effect in tilapias namely $O$. niloticus juveniles taking into account their economical importance and the quality and safety measures of human consumption.

\section{Methods}

\section{Animals}

Animal management procedures were undertaken in accordance with the requirements of the Institutional Animal Care and Use Committee (IACUC), Menoufia University, Egypt. The protocol of this study has been approved by the ethics review board of the IACUC of Faculty of Science (ID: MUFS-F-EC-1-20). The experiments in this study were in compliance with the ARRIVE guidelines.

Juveniles of 0 . niloticus $(30.4 \pm 9.3 \mathrm{~g}, 11.9 \pm 1.3 \mathrm{~cm}$ ) were supplied by the Fish Hatchery Station of Kaferelsheikh Governorate, Egypt. Fish were acclimatized for 14 days in dechlorinated tap water aquaria (50 $\mathrm{L})$. The constant aeration was performed using electric air pumps. Water conditions were constant at $21.35 \pm 0.81^{\circ} \mathrm{C}$ temperature, $6.5 \pm 0.55 \mathrm{pH}, 276 \pm 0.39 \mu \mathrm{sm}^{-1}$ conductivity, $0.04 \pm 0.03$ of ammonia concentration. The commercial fish diet containing $25 \%$ protein (Tag-elmlook Company, Baltim, KaferElsheikh) was used in feeding. Feeding was suspended $48 \mathrm{~h}$ prior to the start of the experiment and during the experiments.

\section{Chemicals}

- Imidacloprid (Imid), [1-(6-chloropyridin-3-ylmethyl)-N- nitroimidazolidin-2-/ylideneamine]. It was purchased in a commercial form (CLAS 35\% SC, CAS. 1811, PHARMA CURE, Wady Alntron, Egypt). 
- Ascorbic acid $\left(\mathrm{C}_{6} \mathrm{H}_{8} \mathrm{O}_{6}\right.$, M.W. 176.13, assay 99\%, S.D. Fine-Chem. Ltd., K07Z0907/1710/62, Mumbai, India)

\section{Experimental design, dosing and sampling}

The lethal concentration $50\left(\mathrm{LC}_{50}\right)$ of Imid to Nile tilapia juveniles was determined $\left(72 \mathrm{~h}-\mathrm{LC}_{50}\right)$ in this study according to Yuniari et al. ${ }^{69}$. The study was carried out using two doses of Imid sub-lethal concentration $\left(1 / 10 \& 1 / 20\right.$ of $\left.L_{50}\right)$ and a concentration of $50 \mathrm{ppm}$ for Asc as described by Ghazanfar et al. ${ }^{33}$. Fish were randomly divided into six groups ( $n=10$ fish per group, five of them were processed for chromosomal preparation and the remained five fish were used for other investigations). Fish were maintained in glass aquaria containing dechlorinated tap water $(50 \mathrm{~L})$. Frist group was used as control and the second group was exposed to Asc only. Other two groups were subjected to Imid concentrations of $17.5 \mathrm{ppm}\left(1 / 10\right.$ of $\left.\mathrm{LC}_{50}\right)$ and $8.75 \mathrm{ppm}\left(1 / 20\right.$ of $\left.\mathrm{LC}_{50}\right)$. Finally, two co-treatment groups were exposed to Imid and Asc (17.5 ppm -Imid + 50 ppm Asc) and ( 8.75 ppm-Imid + 50 ppm Asc). The experiment was performed for 21 days according to Al-Anazi et al. ${ }^{27,33}$, under static conditions. Water renewal (30\%) was done daily to overcome the daily degradation of Imid and Asc as previously described ${ }^{33,70}$ and in agreement with the HPLC results.. Further, all aquaria were laterally covered with black sheets to minimize the effect of light on Imid and Asc, where, Asc is light sensitive ${ }^{71}$. During the experiments, temperature measurements, dissolved oxygen, ammonia levels, $\mathrm{pH}$ and water conductivity were adjusted as acclimatization conditions.

After the exposure period, caudal vein puncture was used to collect blood samples and processed for MN test and comet assay. After blood sampling fish were sacrificed on ice immediately by medullar sectioning for liver removal. Organs were quickly stored in $-20^{\circ} \mathrm{C}$ for gene expression and biochemical analyses. In addition, samples of liver and gills were freshly processed for comet assay.

For biochemical analyses, samples of liver tissues were homogenized (1:10 wt./v) in a 0.1M phosphate buffer solution ( $\mathrm{pH} 7.1$ containing $1 \mathrm{mM}$ Mercaptoethanol and 2mM EDTA). Samples were centrifuged $\left(15,000 \mathrm{xg}, 20 \mathrm{~min}, 4^{\circ} \mathrm{C}\right)$ and the supernatants were stored at $-80^{\circ} \mathrm{C}$ for subsequent biochemical analyses. For all biochemical biomarkers assessment, the determination of liver protein content was done 72. Experiments were done in triplicates.

\section{Assessment of Imid and Asc degradation in water}

HPLC quantification of Imid and Asc in water samples was done using High performance liquid chromatography (HPLC) analysis. After $24 \mathrm{~h}$ of exposure period, water samples were collected in clean amber glass bottles and HPLC analysis was performed. The ZORBAX Eclipsed XDB-C18 column (4.6x $150 \mathrm{~mm}, 5 \mathrm{um})$ and Zorbax C8 column (4.6 mm x $150 \mathrm{~mm}$ i.d., $5 \mu \mathrm{m}$ ) were used for chromatographic separation of Imid and Asc, respectively. The mobile phase consisted of methanol: water (60: 40\%, respectively) for Imid and $0.01 \%$ trifluoroacetic acid in water and methanol (70: $30 \%$, respectively) for Asc. 
Identification and quantification of Imid was performed by HPLC-DAD using an Agilent 1260 device (Agilent Technologies, CA, USA).

\section{Biochemical analyses}

The homogenized liver supernatants were used to determine the lipid peroxidation as malondialdehyde (MDA) levels ${ }^{73}$. Results were presented in $\mathrm{nmol} / \mathrm{mg}$ protein. The activities of superoxide dismutase (SOD) ${ }^{74}$, catalase (CAT) ${ }^{75}$, and glutathione peroxidase (GPX) ${ }^{76}$ were determined colorimetrically and presented as $\mathrm{U} / \mathrm{mg}$ protein. The analyses were done using colorimetric Bio-Diagnostics kits (BioDiagnostics Co, Giza, Egypt) according to the manufacturer's instructions (CAT. No. MDA, MD 2529; SOD, SD 2521; CAT, CA 2517 \& GPX, Gp 2524).

\section{Gene expression}

Quantitative real-time polymerase chain reaction (qRT-PCR) was carried out to evaluate the expression of liver SOD, CAT and GPX genes in tilapias. Used primer sequences were illustrated in Table (1). The total RNA was extracted from tissue using the RNeasy Kit (Qiagen, Hilden, Germany) following the company's protocol. The Reverse Transcript kit (Qiagen, Hilden, Germany) was used cDNA synthesis. The qPCR of the $\beta$ actin (a housekeeping gene) and studied genes were performed using a Qiagen QuantiTect SYBR Green PCR kit in a Rotor-Gene Q cycler (Qiagen, Hilden, Germany).

Table 1

Sequences of used primers.

\begin{tabular}{|c|c|c|c|}
\hline Primer & Primer Sequence $\left(5^{\prime} \rightarrow 3^{\prime}\right)$ & Accession number & Reference \\
\hline \multirow[t]{2}{*}{ SOD } & F:GGTGCCCTGGAGCCCTA & JF801727.1 & \multirow[t]{2}{*}{43} \\
\hline & R: ATGCGAAGTCTTCCACTGTC & & \\
\hline \multirow[t]{2}{*}{ CAT } & F: TCCTGAATGAGGAGGAGCGA & JF801726.1 & \multirow[t]{2}{*}{43} \\
\hline & R: ATCTTAGATGAGGCGGTGATG & & \\
\hline \multirow[t]{2}{*}{ GPX } & F: CCAAGAGAACTGCAAGAGA & FF280316.1 & \multirow[t]{2}{*}{43} \\
\hline & R: CAGGACACGTCATTCCTACAC & & \\
\hline \multirow[t]{2}{*}{$\beta$-actin } & F: CAATGAGAGGTTCCGTTGC & EF206801 & \multirow[t]{2}{*}{77} \\
\hline & R: AGGATTCCATACCAAGGAAGG & & \\
\hline
\end{tabular}

\section{Genotoxic analysis}

\section{- Comet assay}

Single cell gel electrophorese of erythrocytes, gills and liver cells was performed according to Singh et al. 78 . Briefly, the tissues of tested organs were cut into small pieces and homogenized gently in a phosphate buffer (1:10 wt. /v). The homogenate was meshed to obtain a cell suspension then centrifuged at $200 \mathrm{xg}$ 
for 5 min to obtain the pellet of individual cells. On glass slides precoated with normal (1\%) melting point agarose, cells of tested organs were suspended in low melting point agarose $(0.5 \%)$ between two layers of ultra-pure normal melting agarose (0.7\%). The slides were subjected to: a) lysis: $2 \mathrm{~h}$ at $4{ }^{\circ} \mathrm{C}$, in dark, in lysis buffer $(2.5 \mathrm{M} \mathrm{NaCl}, 100 \mathrm{mM}$ EDTA, $10 \mathrm{mM}$ Tris, $1 \%$ sodium lauroyl sarcosinate, $10 \%$ DMSO, $1 \mathrm{~mL}$ Triton X-100, $\mathrm{pH} 10.0)$; b) DNA denaturation: in an electrophoresis buffer $(0.3 \mathrm{~N} \mathrm{NaOH}, 1 \mathrm{mMEDTA}, \mathrm{pH}>13$, at $4{ }^{\circ} \mathrm{C}$ ) for $30 \mathrm{~min}$ in the dark; c) electrophoresis: $20 \mathrm{~min}, 300 \mathrm{~mA}, 25 \mathrm{~V}, 0.7 \mathrm{e} 0.8 \mathrm{~V} \mathrm{~cm}^{-1}$; and d) neutralization: three rinses for $5 \mathrm{~min}$ each with neutralizing buffer ( $0.4 \mathrm{M}$ Tris, $\mathrm{pH} 7.5)$. For visualization of DNA damage, staining was done using $20 \mu \mathrm{g} / \mathrm{mL}$ of ethidium bromide. At $400 \times$ magnification of at least 500 nuclei, the observation was done using a fluorescent microscope (Olympus BX41, Tokyo, Japan). The DNA damage was quantified by the appearance of the migrated tail and classified into two comet classes (normal and damaged).

\section{- Micronuclei (MN) and erythrocytic nuclear abnormalities (ENA)}

Erythrocytic micronuclei (MN) and nuclear abnormalities (ENA) were investigated in fish groups after various treatments. In brief, $O$. niloticus blood samples smeared on glass slides. After air dryness, cells were fixed in absolute methanol for $15 \mathrm{~min}$ and stained with hematoxylin and eosin stain for $20 \mathrm{~min}$ each. The mean frequency of MN and NA per group was determined by the analysis of 1000 cells per fish (\%). Kidney-shaped, lobulated, segmented nuclei, and binucleated cells were considered as nuclear abnormalities.

\section{- Chromosomes preparation}

Chromosomal preparation was performed from tilapia Kidneys and the mitotic index was calculated ${ }^{79,80}$. Briefly, a volume of $1 \mathrm{~mL} / 100 \mathrm{~g}$ b.wt. of colchicine (0.05\%) was injected into the abdominal cavity of fish two hours prior to the dissection. After the kidney removal, it was cut into small pieces before mixing with $5 \mathrm{~mL}$ of the hypotonic solution $(0.075 \mathrm{M} \mathrm{KCl})$. All large pieces of the kidney tissues were discarded. At room temperature, the suspended cells was incubated for 20 minutes, and centrifuged for $5 \mathrm{~min}$ at 400 g. Dropwisely, cells were applied to the fixation step using $5 \mathrm{~mL}$ of fresh cold fixative (3 methanol: 1 acetic acid) before centrifugation. The fixation process was repeated until the supernatant was cleared. A concentrated volume of each tube was dropped $15 \mathrm{~cm}$ high on a clean and $70 \%$ cold ethanol-dipped glass slide and left to dry at room temperature. The slide was conventionally stained for 30 minutes with $20 \%$ Giemsa solution, $\mathrm{pH} 6.8$. Metaphases and prophases were evaluated over 1000 nuclei per slide to calculate the mitotic index.

\section{Statistical analysis}

After data normality checking (Shapiro Wilk test) and homoscedasticity (Levene's test) mean values of all groups were cross-compared using parametric (ANOVA) by multiple comparison post hoc test, Dunnett's test. Also, the significance between Insecticide-treated group and the corresponding co-treatment group was compared by independent $t$ test. The data shown in the graphs were represented as means $\pm S D$. The 
significant level of differences was considered at $P<0.05$. Statistical analyses were done using the IBM SPSS software version 21.1 (New York, NY, USA).

\section{Declarations}

\section{Data availability}

All data of this study are introduced in this published article.

\section{Acknowledgements}

Gaber A.M. Mersal is very grateful to the Taif University Researchers Supporting Project number (TURSP2020/14),Taif University, Taif, Saudi Arabia. Hesham R. El-Seedi is very grateful to the Swedish Research links Grant VR 05908, Sweden, for the financial support.

\section{Author contributions}

Conceptualization, I.E.-G., Methodology, I.E.-G. and R.E.., Validation, I.E.-G., E.K. and A.A., Formal Analysis, R.E., Investigation, I.E.-G. and R.E, Resources, H.R.E.-S., R.E. and G.A.M.M., Data Curation, R.E. and I.E.-G, Writing-Original Draft Preparation, I.E.-G and R.E., Writing-Review \& Editing, E.K., A.A., G.A.M.M. and H.R.E.S., Supervision, E.K, A.A. and I.E.-G, project administration, I.E.-G., funding acquisition, H.R.E.-S., G.A.M.M. and R.E. All authors have read and agreed to the published version of the manuscript.

\section{Funding}

Taif University Researchers Supporting Project number (TURSP-2020/14),Taif University, Taif, Saudi Arabia. The Swedish Research links Grant VR 2016-05885 and the Department of Molecular Biosciences, Wenner-Grens Institute, Stockholm University, Sweden.

\section{Competing interests}

All authors declare that no conflict of interest regarding this article.

\section{Correspondence}

Requests for materials should be addressed to I. E.-G. or H.R.E.-S.

\section{References}

1. El-Sayed, Y. S., Saad, T. T. \& El-Bahr, S. M. Acute intoxication of deltamethrin in monosex Nile tilapia, Oreochromis niloticus with special reference to the clinical, biochemical and haematological effects. Environ. Toxicol. Pharmacol. 24, 212-217 (2007).

2. Suman, B., Nilanjan, C. H., Lopamudra, G. \& Sayan,Ganguly P, M. K. Modulation of blood profile of juvenile Cyprinus carpio exposed to imidacloprid. Int. J. of Life Sci. 5, 627-630 (2017). 
3. Santos, Elton Lima, WINTERLE, Waleska de Melo Costa, Ludke, Maria do Carmo M. M., Barbosa, J. M. Digestibilidade de ingredientes alternativos para tilápia-do-nilo (Oreochromis niloticus): Revisão. Rev. Bras. Eng. Pesca 3, 135-149 (2008).

4. Américo-Pinheiro, J. H. P. et al. Sublethal Effects of Imidacloprid in Hematological Parameters of Tilapia (Oreochromis niloticus). Water. Air. Soil Pollut. 230, (2019).

5. Tomlin. the pesticide manual 12 edition. Farnham, Surrey, UK : British Crop Protection Council (2000).

6. Vieira, C. E. D., Pérez, M. R., Acayaba, R. D. A., Raimundo, C. C. M. \& dos Reis Martinez, C. B. DNA damage and oxidative stress induced by imidacloprid exposure in different tissues of the Neotropical fish Prochilodus lineatus. Chemosphere (2018). doi:10.1016/j.chemosphere.2017.12.077

7. Mason, R. Immune Suppression by Neonicotinoid Insecticides at the Root of Global Wildlife Declines. J. Enviromental Immunol. Toxicol. 1, 3 (2013).

8. Berheim, E. H. et al. Effects of Neonicotinoid Insecticides on Physiology and Reproductive Characteristics of Captive Female and Fawn White-tailed Deer. Sci. Rep. 9, 1-10 (2019).

9. Jeschke, P., Nauen, R., Schindler, M. \& Elbert, A. Overview of the status and global strategy for neonicotinoids. J. Agric. Food Chem. (2011). doi:10.1021/jf101303g

10. Goulson, D. An overview of the environmental risks posed by neonicotinoid insecticides. J. Appl. Ecol. 50, 977-987 (2013).

11. Valavanidis, A., Vlahogianni, T., Dassenakis, M. \& Scoullos, M. Molecular biomarkers of oxidative stress in aquatic organisms in relation to toxic environmental pollutants. Ecotoxicol. Environ. Saf. 64, 178-189 (2006).

12. Özkan, F., Gündüz, S. G., Berköz, M., Hunt, A. Ö. \& Yalın, S. The protective role of ascorbic acid (vitamin $\mathrm{C}$ ) against chlorpyrifos-induced oxidative stress in Oreochromis niloticus. Fish Physiol. Biochem. 38, 635-643 (2012).

13. Saeed, M., Amen, A., Fahmi, A., Garawani, I. El \& Sayed, S. The possible protective effect of Coriandrum sativum seeds methanolic extract on hepato-renal toxicity induced by sodium arsenite in albino rats. J. Appl. Pharm. Sci. 4, 044-051 (2014).

14. Gibbons, D., Morrissey, C. \& Mineau, P. A review of the direct and indirect effects of neonicotinoids and fipronil on vertebrate wildlife. Environ. Sci. Pollut. Res. 22, 103-118 (2015).

15. Özdemir, S., Altun, S. \& Arslan, H. Imidacloprid exposure cause the histopathological changes, activation of TNF-a iNOS, 8-OHdG biomarkers, and alteration of caspase 3, iNOS, CYP1A, MT1 gene expression levels in common carp (Cyprinus carpio L.). Toxicol. Reports 5, 125-133 (2018).

16. Iturburu, F. G., Simoniello, M. F., Medici, S., Panzeri, A. M. \& Menone, M. L. Imidacloprid Causes DNA Damage in Fish: Clastogenesis as a Mechanism of Genotoxicity. Bull. Environ. Contam. Toxicol. 100, 760-764 (2018).

17. Shan, Y., Yan, S., Hong, X., Zha, J. \& Qin, J. Effect of imidacloprid on the behavior, antioxidant system, multixenobiotic resistance, and histopathology of Asian freshwater clams (Corbicula fluminea). Aquat. Toxicol. 218, 105333 (2020). 
18. Anderson, S. et al. Genetic and molecular ecotoxicology: A research framework. Environ. Health Perspect. 102, 3-8 (1994).

19. Bolognesi, C., Perrone, E., Roggieri, P., Pampanin, D. M. \& Sciutto, A. Assessment of micronuclei induction in peripheral erythrocytes of fish exposed to xenobiotics under controlled conditions. Aquat. Toxicol. 78, S93-S98 (2006).

20. Guilherme, S., Santos, M. A., Barroso, C., Gaivão, I. \& Pacheco, M. Differential genotoxicity of Roundup ${ }^{\circledR}$ formulation and its constituents in blood cells of fish (Anguilla anguilla): Considerations on chemical interactions and DNA damaging mechanisms. Ecotoxicology 21, 1381-1390 (2012).

21. Hoshina, M. M. \& Marin-Morales, M. A. Evaluation of the Genotoxicity of Petroleum Refinery Effluents Using the Comet Assay in Oreochromis niloticus (Nile tilapia). J. Brazilian Soc. Ecotoxicol. 5, 75-79 (2010).

22. Poletta, G. L. et al. Comet assay in gill cells of Prochilodus lineatus exposed in vivo to cypermethrin. Pestic. Biochem. Physiol. 107, 385-390 (2013).

23. Cheng, C. H. et al. Effect of nitrite exposure on oxidative stress, DNA damage and apoptosis in mud crab (Scylla paramamosain). Chemosphere 239, 124668 (2020).

24. Alvim, T. T. \& Martinez, C. B. dos R. Genotoxic and oxidative damage in the freshwater teleost Prochilodus lineatus exposed to the insecticides lambda-cyhalothrin and imidacloprid alone and in combination. Mutat. Res. - Genet. Toxicol. Environ. Mutagen. 842, 85-93 (2019).

25. El-Garawani, I. M., El-Nabi, S. H., El-Shafey, S., Elfiky, M. \& Nafie, E. Coffea arabica Bean Extracts and Vitamin C: A Novel Combination Unleashes MCF-7 Cell Death. Curr. Pharm. Biotechnol. (2019). doi:10.2174/1389201020666190822161337

26. Garg, M. C. \& Bansal, D. D. Protective antioxidant effect of vitamins $C$ and $E$ in streptozotocin induced diabetic rats. Indian J. Exp. Biol. 38, 101-104 (2000).

27. Marim Saleh Al-Anazi, Promy Virk, Ma. E. and M. I. S. Ameliorative effects of Rosmarry on cadmium. J. Environ. Biol. 36, 1401-1408 (2015).

28. Erdman, J. W., MacDonald, I. A. \& Zeisel, S. H. Present Knowledge in Nutrition: Tenth Edition. Present Knowledge in Nutrition: Tenth Edition (2012). doi:10.1002/9781119946045

29. Bruno, R. S. et al. Faster plasma vitamin E disappearance in smokers is normalized by vitamin $C$ supplementation. Free Radic. Biol. Med. 40, 689-697 (2006).

30. Bebe, F. N. \& Panemangalore, M. Exposure to low doses of endosulfan and chlorpyrifos modifies endogenous antioxidants in tissues of rats. J. Environ. Sci. Heal. - Part B Pestic. Food Contam. Agric. Wastes 38, 349-363 (2003).

31. Yen, G. C., Duh, P. Der \& Tsai, H. L. Antioxidant and pro-oxidant properties of ascorbic acid and gallic acid. Food Chem. 79, 307-313 (2002).

32. Fathima, P. S., Priyatha, C. V \& Chitra, K. C. Ameliorating Effect of Vitamin C on Acid Orange 7 Induced Oxidative Stress in the Gill of the Fish, Anabas testudineus (Bloch , 1792 ). 8, 15-27 (2018). 
33. Ghazanfar, M., Shahid, S. \& Qureshi, I. Z. Vitamin C attenuates biochemical and genotoxic damage in common carp (Cyprinus carpio) upon joint exposure to combined toxic doses of fipronil and buprofezin insecticides. Aquatic Toxicology 196, (Elsevier B.V., 2018).

34. Verlhac, V., Obach, A., Gabaudan, J., Schüep, W. \& Hole, R. Immunomodulation by dietary vitamin C and glucan in rainbow trout (Oncorhynchus mykiss). Fish Shellfish Immunol. 8, 409-424 (1998).

35. Ge, W. et al. Oxidative stress and DNA damage induced by imidacloprid in zebrafish (Danio rerio). J. Agric. Food Chem. (2015). doi:10.1021/jf504895h

36. Zhang, T. et al. Effects of acute ammonia toxicity on oxidative stress, DNA damage and apoptosis in digestive gland and gill of Asian clam (Corbicula fluminea). Fish Shellfish Immunol. 99, 514-525 (2020).

37. Burk, R., Hill, K. \& Nutrition, A. M.-T. J. of. Selenoprotein metabolism and function: evidence for more than one function for selenoprotein P. J Nutr. 133(5 Suppl 1):1517S-20S (2003).

38. Atencio, L. et al. Effects of dietary selenium on the oxidative stress and pathological changes in tilapia (Oreochromis niloticus) exposed to a microcystin-producing cyanobacterial water bloom. Toxicon (2009). doi:10.1016/j.toxicon.2008.11.011

39. Pacini, N. et al. Detoxifying response in juvenile tench fed by selenium diet. (2011). doi:10.1016/j.etap.2011.10.004

40. Neamat-Allah, A. N. F., Mahmoud, E. A. \& Abd El Hakim, Y. Efficacy of dietary Nano-selenium on growth, immune response, antioxidant, transcriptomic profile and resistance of Nile tilapia, Oreochromis niloticus against Streptococcus iniae infection. Fish Shellfish Immunol. 94, 280-287 (2019).

41. Saddick, S., Afifi, M. \& Abu Zinada, O. A. Effect of Zinc nanoparticles on oxidative stress-related genes and antioxidant enzymes activity in the brain of Oreochromis niloticus and Tilapia zillii. Saudi J. Biol. Sci. 24, 1672-1678 (2017).

42. Gatta, P. P., Pirini, M., Testi, S., Vignola, G. \& Monetti, P. G. The influence of different levels of dietary vitamin E on sea bass Dicentrarchus labrax flesh quality. Aquac. Nutr. 6, 47-52 (2000).

43. Neamat-Allah, A. N. F., Mahmoud, E. A., Abd, Y. \& Hakim, E. Efficacy of dietary Nano-selenium on growth, immune response, antioxidant, transcriptomic profile and resistance of Nile tilapia, Oreochromis niloticus against Streptococcus iniae infection. Fish Shellfish Immunol. 94, 280-287 (2019).

44. Nikinmaa, M. \& Rytkönen, K. T. Functional genomics in aquatic toxicology-Do not forget the function. Aquat. Toxicol. 105, 16-24 (2011).

45. El-Garawani, I. M. et al. A newly isolated strain of Halomonas sp. (HA1) exerts anticancer potential via induction of apoptosis and G2/M arrest in hepatocellular carcinoma (HepG2) cell line. Sci. Rep. (2020). doi:10.1038/s41598-020-70945-8

46. Iturburu, F. G. et al. Uptake, distribution in different tissues, and genotoxicity of imidacloprid in the freshwater fish australoheros facetus. Wiley Online Libr. 36, 699-708 (2017). 
47. Paravani, E., Simoniello M. F., Poletta G. L. \& Casco V. H. Cypermethrin induction of DNA damage and oxidative stress in zebrafish gill cells. Ecotoxicol Environ Saf. 30, 1-7 (2019).

48. Saxena, K. B., Kumar, R. V, Srivastava, N. \& Shiying, B. A cytoplasmic-nuclear male-sterility system derived from a cross between Cajanus cajanifolius and Cajanus cajan. Euphytica 145, 289-294 (2005).

49. Bolognesi, C. \& Cirillo, S. Genotoxicity biomarkers in aquatic bioindicators. Curr. Zool. 60, 273-284 (2014).

50. Grummt, T., Grummt, H. J. \& Schott, G. Chromosomal aberrations in peripheral lymphocytes of nurses and physicians handling antineoplastic drugs. Mutat. Res. Lett. 302, 19-24 (1993).

51. Alimba, C. G., Ajiboye, R. D. \& Fagbenro, O. S. Dietary ascorbic acid reduced micronucleus and nuclear abnormalities in Clarias gariepinus (Burchell 1822) exposed to hospital effluent. Fish Physiol.

Biochem. 43, 1325-1335 (2017).

52. Moore, P. D., Patlolla, A. K. \& Tchounwou, P. B. Cytogenetic evaluation of malathion-induced toxicity in Sprague-Dawley rats. Mutat. Res. - Genet. Toxicol. Environ. Mutagen. 725, 78-82 (2011).

53. Mužinić, V., Ramić, S. \& želježić, D. Chromosome Missegregation and Aneuploidy Induction in Human Peripheral Blood Lymphocytes In vitro by Low Concentrations of Chlorpyrifos, Imidacloprid and aCypermethrin. Environ. Mol. Mutagen. (2019). doi:10.1002/em.22235

54. Ali, D. et al. Assessment of genotoxic and mutagenic effects of chlorpyrifos in freshwater fish Channa punctatus (Bloch) using micronucleus assay and alkaline single-cell gel electrophoresis. Food Chem. Toxicol. (2009). doi:10.1016/j.fct.2008.12.021

55. El-Garawani, I., Hassab, S., Nabi, E. \& El-Ghandour, E. the Protective Effect of (Foeniculum Vulgare) Oil on Etoposide-Induced Genotoxicity on Male Albino Rats. Eur J Pharm Med Res 4, 180-194 (2017).

56. El-Garawani, I. et al. In vitro antigenotoxic, antihelminthic and antioxidant potentials based on the extracted metabolites from lichen, candelariella vitellina. Pharmaceutics (2020). doi:10.3390/pharmaceutics12050477

57. Ojha, A. \& Srivastava, N. In vitro studies on organophosphate pesticides induced oxidative DNA damage in rat lymphocytes. Mutat. Res. - Genet. Toxicol. Environ. Mutagen. (2014). doi:10.1016/j.mrgentox.2014.01.007

58. Wang, J. et al. The enzyme toxicity and genotoxicity of chlorpyrifos and its toxic metabolite TCP to zebrafish Danio rerio. Ecotoxicology (2014). doi:10.1007/s10646-014-1321-8

59. Rosenfeld, L. Vitamine-vitamin. The early years of discovery. Clin. Chem. 680-685 (1997).

60. Bigard, A. X. Lésions musculaires induites par l'exercice et surentraînement. in Science and Sports (2001). doi:10.1016/S0765-1597(00)00037-X

61. Padayatty, S. J. et al. Vitamin C as an Antioxidant: Evaluation of Its Role in Disease Prevention. J. Am. Coll. Nutr. 22, 18-35 (2003).

62. Sarma, K. et al. Dietary high protein and vitamin C mitigates endosulfan toxicity in the spotted murrel, Channa punctatus (Bloch, 1793). Sci. Total Environ2009) 3668-73, (12)407 .). 
63. Mirvaghefi, A., Mohsen, \& Hadi Poorbagher, A. Effects of vitamin C on oxidative stress parameters in rainbow trout exposed to diazinon. Ege J. Fish. Aquat. Sci. 33, 113-120 (2016).

64. Reddy Narra, M., Rajender, K., Rudra Reddy, R., Rao, J. V. \& Begum, G. The role of vitamin C as antioxidant in protection of biochemical and haematological stress induced by chlorpyrifos in freshwater fish Clarias batrachus. (2015). doi:10.1016/j.chemosphere.2015.03.006

65. Zhou, Q. et al. Effect of dietary vitamin C on the growth performance and innate immunity of juvenile cobia (Rachycentron canadum). Fish \& Shellfish Immunol. 32 (6), 969-975 (2012).

66. KC, S., Càrcamo, J. M. \& Golde, D. W. Vitamin C enters mitochondria via facilitative glucose transporter 1 (Gluti) and confers mitochondrial protection against oxidative injury. FASEB J. 19, 1657-1667 (2005).

67. Lee, Y. C., Huang, H. Y., Chang, C. J., Cheng, C. H. \& Chen, Y. T. Mitochondrial GLUT10 facilitates dehydroascorbic acid import and protects cells against oxidative stress: Mechanistic insight into arterial tortuosity syndrome. Hum. Mol. Genet. 19, 3721-3733 (2010).

68. Lee, Y., Huang, H. \& ... C. C.-H. molecular. Mitochondrial GLUT10 facilitates dehydroascorbic acid import and protects cells against oxidative stress: mechanistic insight into arterial tortuosity syndrome. Hum Mol Genet. 19 (19), 3721-33 (2010).

69. Yuniari, S. H., Hertika, A. M. S. \& Leksono, A. S. Lethal Concentration 50 (LC50 - 96 hours) Nile Tilapia (Oreochromis niloticus) exposed Cypermethrin-based Pesticide. J. Exp. Life Sci. 6, 58-62 (2016).

70. Redlich, D., Shahin, N., Ekici, P., Friess, A. \& Parlar, H. Kinetical Study of the Photoinduced Degradation of Imidacloprid in Aquatic Media. CLEAN - Soil, Air, Water 35, 452-458 (2007).

71. Çakmakçi, S. \& Turgut, T. Influence of different light sources, illumination intensities and storage times on the vitamin C content in pasteurized milk. Turkish J. Vet. Anim. Sci. 29, 1097-1100 (2005).

72. Bradford, M. M. A Rapid and Sensitive Method for the Quantitation of Microgram Quantities of Protein Utilizing the Principle of Protein-Dye Binding. ANALYTICAL BIOCHEMISTRY 72, (1976).

73. Ohkawa, H., Ohishi, N. \& Yagi, K. Assay for Lipid Peroxides in Animal Tissues by Thiobarbituric Acid Reaction. ANALYTICAL BIOCHEMISTRY 95, (1979).

74. Nishikimi, M., Rao, N., Research, K. Y.-B. and biophysical \& U. The occurrence of superoxide anion in the reaction of reduced phenazine methosulfate and molecular oxygen. Biochem Biophys Res Commun. 46 (2), 849-54 (1972).

75. Aebi, H. Catalase in Vitro. Methods Enzymol. 105, 121-126 (1984).

76. Paglia, D. \& Valentine W. Studies on the quantitative and qualitative characterization of erythrocyte glutathione peroxidase. J Lab Clin Med. 70 (1),158-69 (1967).

77. Abdelazim Islam M, A., Swelum, A. A.-A., Afifi, M. M. \& Alkaladi, A. Oxidative stress in the muscles of the fish Nile tilapia caused by zinc oxide nanoparticles and its modulation by vitamins $\mathrm{C}$ and $\mathrm{E}$. Oxid. Med. Cell. Longev. 6926712 (2018).

78. Singh, N. P., McCoy, M. T., Tice, R. R. \& Schneider, E. L. A simple technique for quantitation of low levels of DNA damage in individual cells. Exp. Cell Res. 175, 184-191 (1988). 
79. Chen, T. \& Ebeling A. Karyological evidence of female heterogamety in the mosquitofish, Gambusia affinis. Copeia, 1, 70-75 (1968).

80. Nanda, I. et al. Chromosomal evidence for laboratory synthesis of a triploid hybrid between the gynogenetic teleost Poecilia formosa and its host species. J. Fish Biol. 47, 619-623 (1995).

Figures

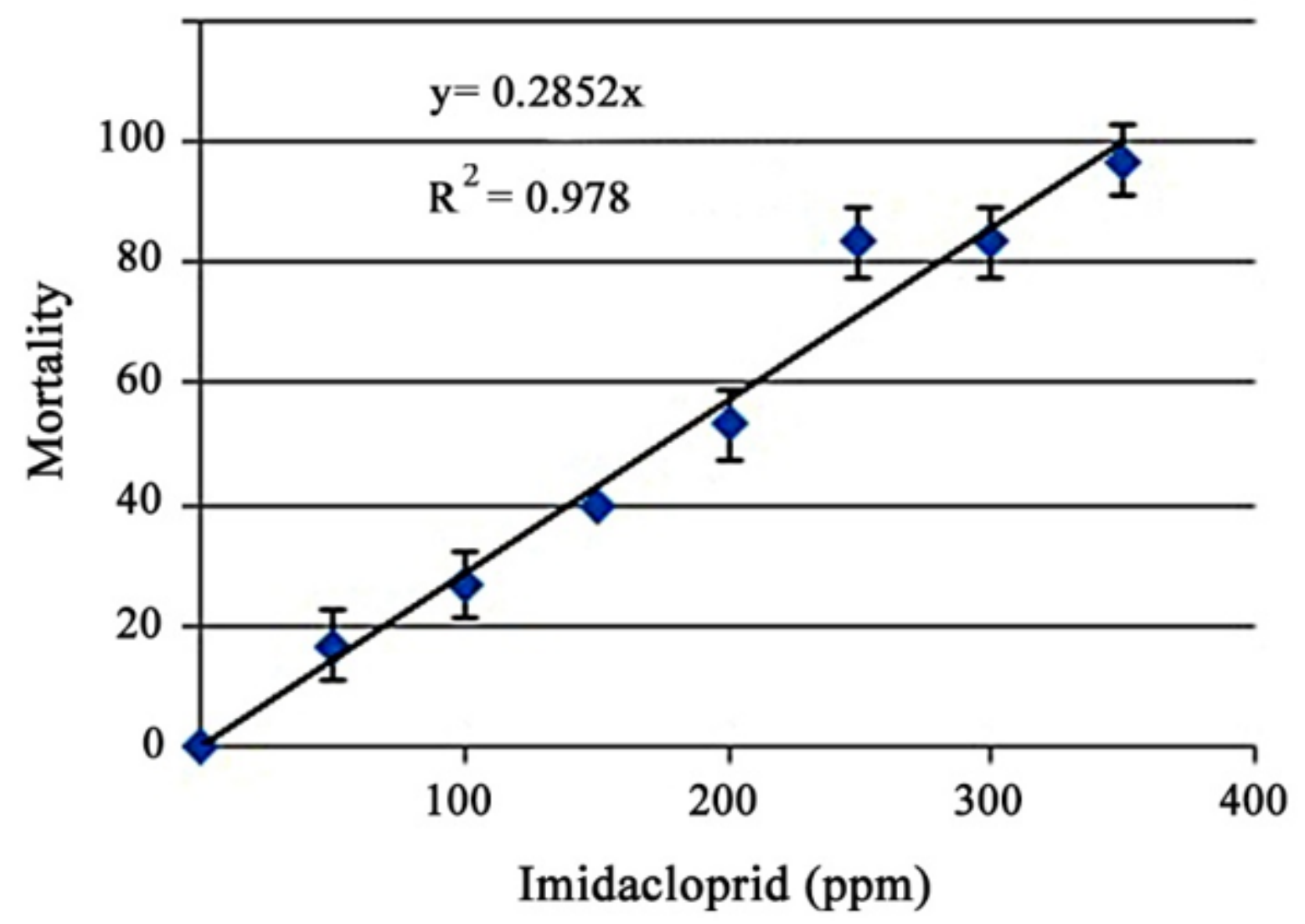

Figure 1

The dose respose of 0 . niloticus exposed to diferent concentrations $(0-350 \mathrm{ppm})$ of $\operatorname{Imid}(\mathrm{n}=10 \mathrm{fish})$. Values were expressed as mean \pm standard deviation (SD), bars refer to SD. 
A

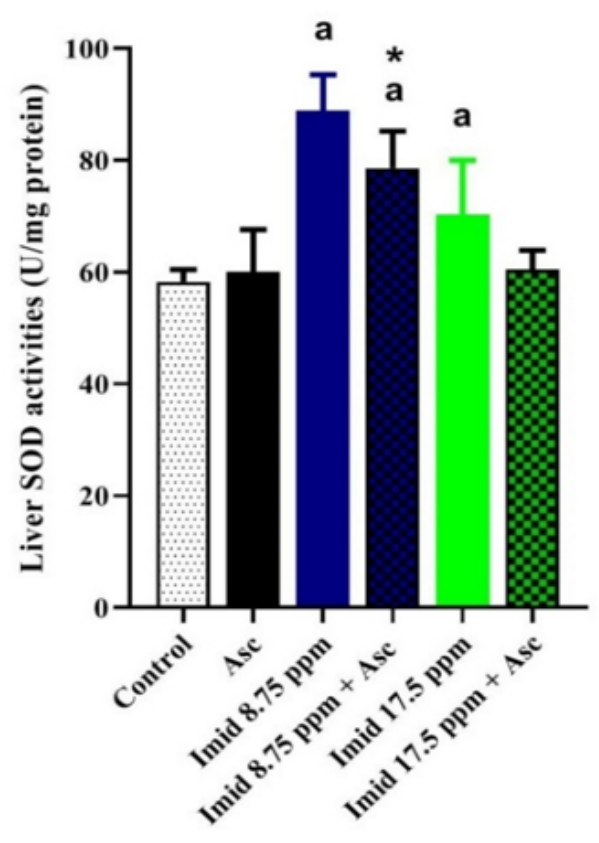

C

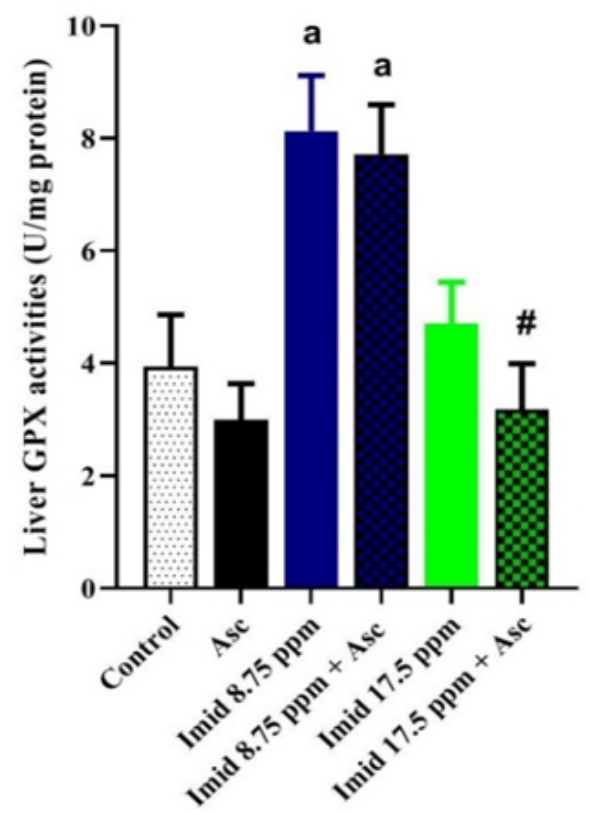

B

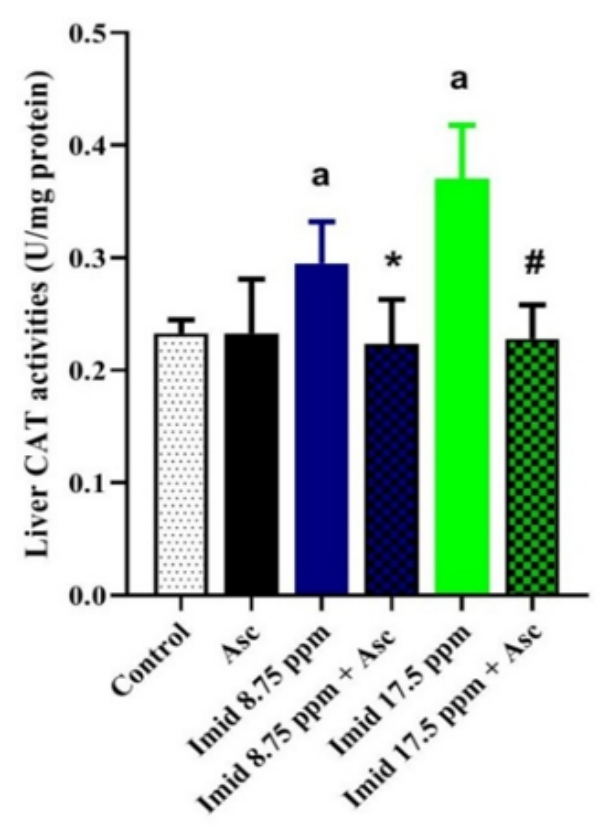

D

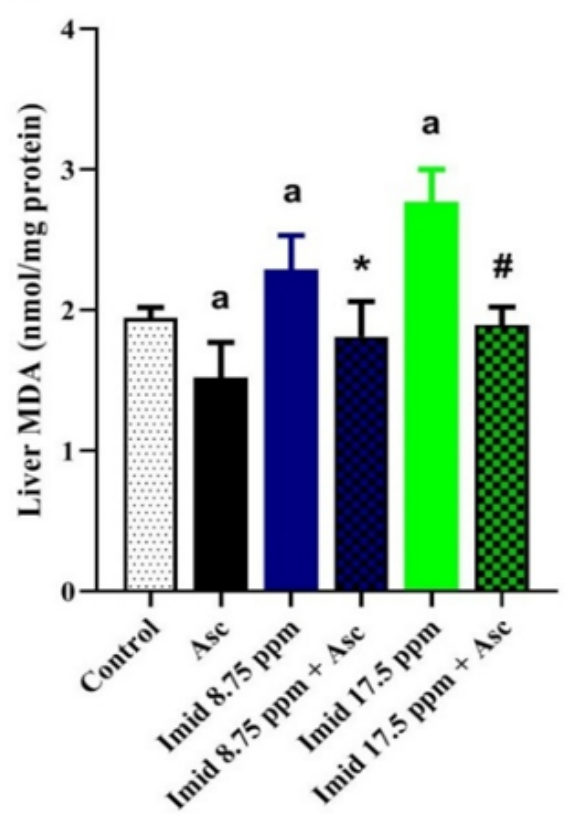

Figure 2

The ameliorative effect of ascorbic acid (Asc) on imidacloprid (Imid)-induced oxidative stress on liver of O. niloticus when administrated for 21 days. A, Superoxide dismutase (SOD), B, Catalase (CAT), C, Glutathione peroxidase (GPX) and D, Lipid peroxides (LPO). Imid was added at concentrations of 8.75 and $17.5 \mathrm{ppm}$ and Asc was applied at $50 \mathrm{ppm}$. Values were expressed as mean \pm standard deviation (SD), bars refer to $S D$, ( $n=5$ fish). a indicates significant difference respecting the control group ( $\mathrm{p} \otimes 0.05)$, *, \# 
indicates significant difference between co-treatment and corresponding Imid-exposed (17.5 \& 8.75 ppm) groups respectively $(\mathrm{p} \otimes 0.05)$.

A

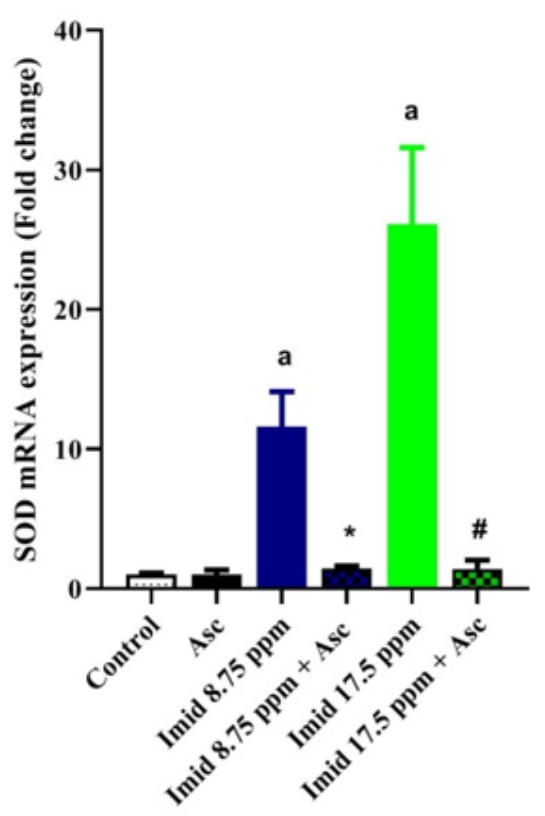

B

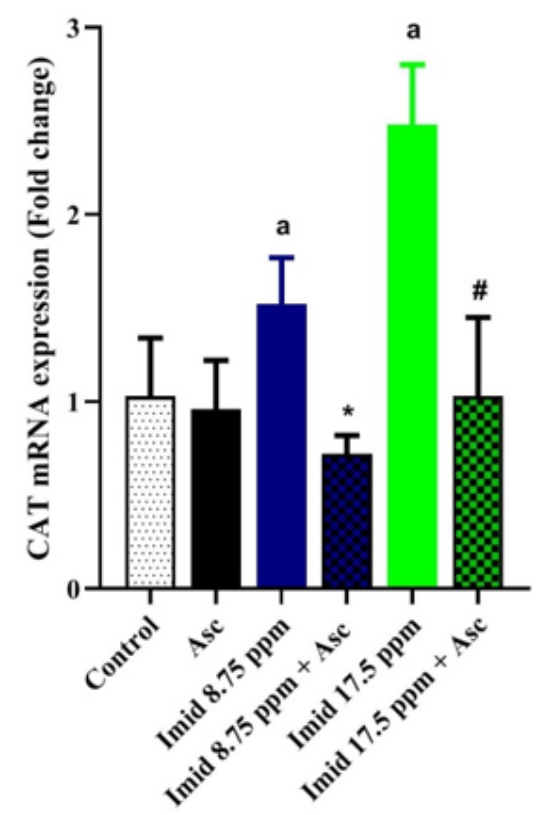

C

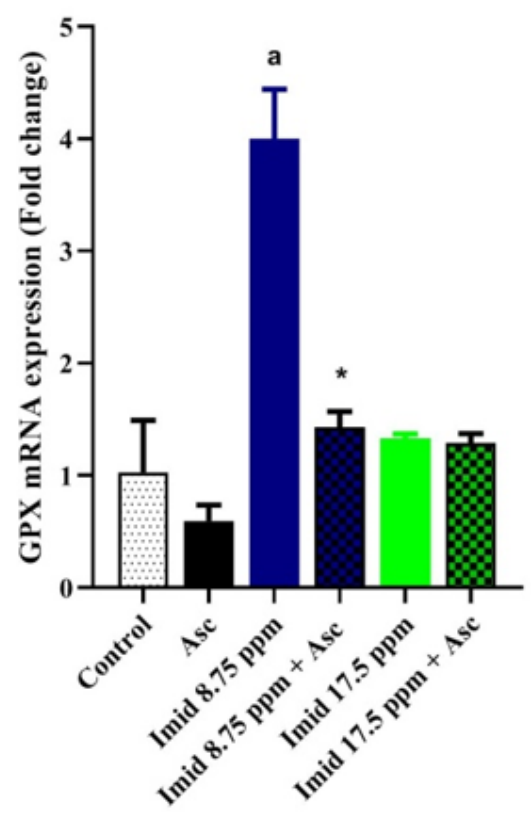

Figure 3

The ameliorative effect of ascorbic acid (Asc) on relative mRNA levels of imidacloprid (Imid)-exposed groups on liver of O. niloticus. The concentrations of Imid (8.75 \& $17.5 \mathrm{ppm})$ and Asc (50 ppm) were administrated for 21 days. Superoxide dismutase, SOD (A), Catalase, CAT (B), Glutathione peroxidase, GPX (C). Values were expressed as mean \pm standard devia-tion (SD), bars refer to SD, ( $n=5$ fish). a indicates significant difference respecting the control group ( $\mathrm{p} \otimes 0.05)$, * \# indicates significant difference between co-treatment and corresponding Imid-exposed (17.5 \& $8.75 \mathrm{ppm})$ groups respectively $(\mathrm{p} \otimes 0.05)$. 


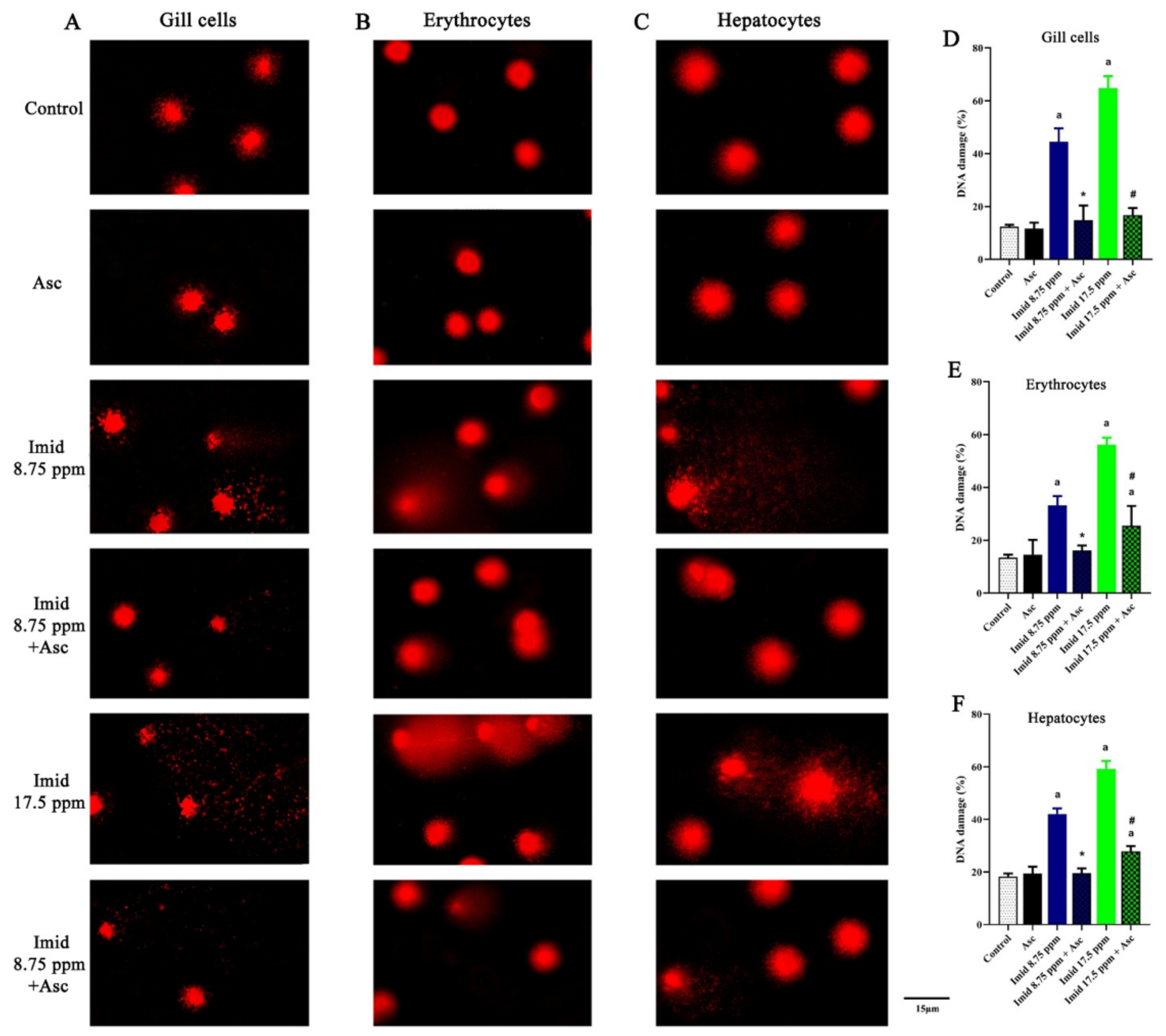

\section{Figure 4}

Representative micro-photographs of single cell gel electrophoresis (comet assay), stained with ethidium bromide, shows the protective effect of ascorbic acid (Asc, $50 \mathrm{ppm}$ ) on DNA damage of gill cells (A\&D), erythrocytes (B\&E) and hepatocytes (C\&F) of 0 . niloticus induced by the administration of imidacloprid (Imid) concentrations ( $8.75 \& 17.5 \mathrm{ppm})$ for 21 days. Values were expressed as mean \pm standard deviation (SD), bars refer to $S D$, ( $n=5$ fish). a indicates significant difference re-specting the control group $(\mathrm{p} \otimes 0.05), *$, \# indicates significant difference between co-treatment and corresponding Im-id-exposed (17.5 \& $8.75 \mathrm{ppm})$ groups respectively ( $\mathrm{p} \otimes 0.05)$. 

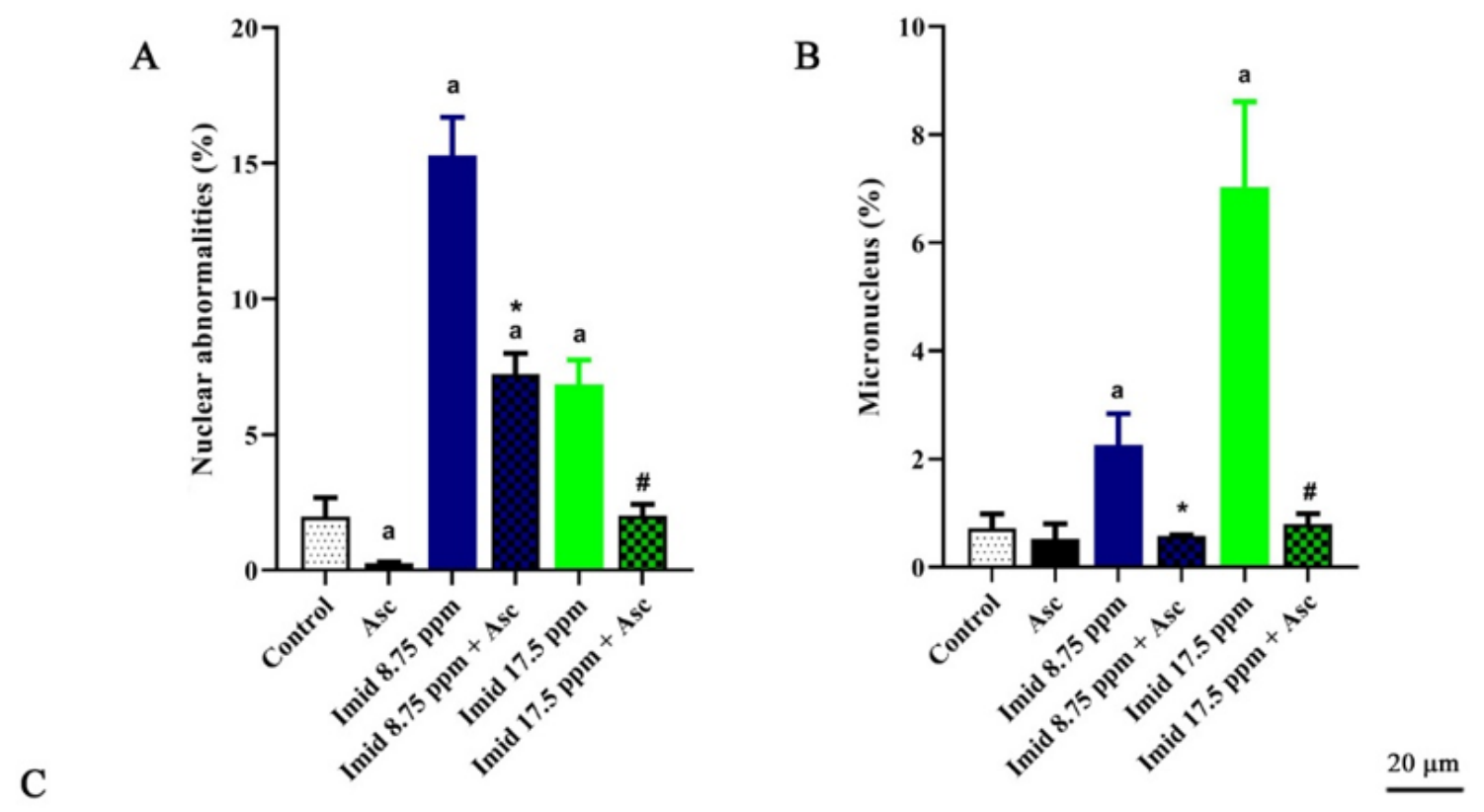

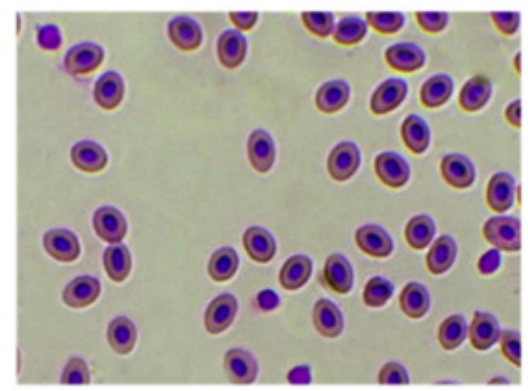

Control

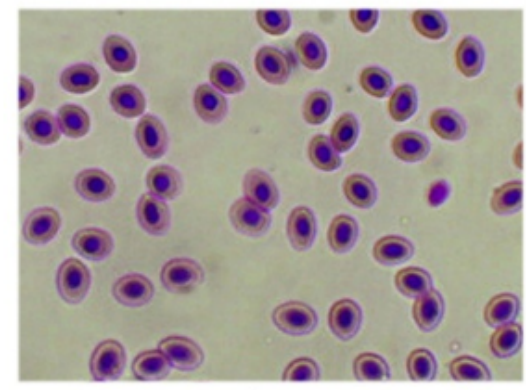

Asc

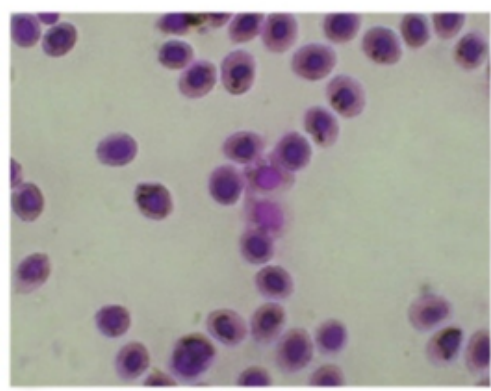

Imid 8.75 ppm

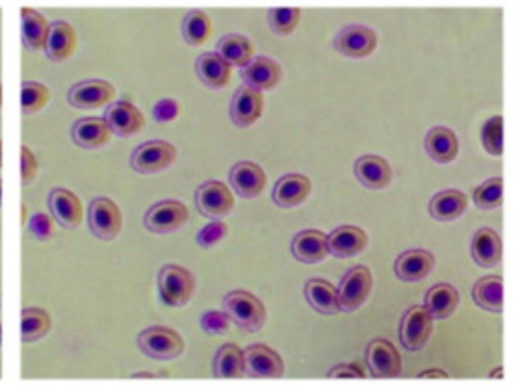

Imid $8.75 \mathrm{ppm}+\mathrm{Asc}$

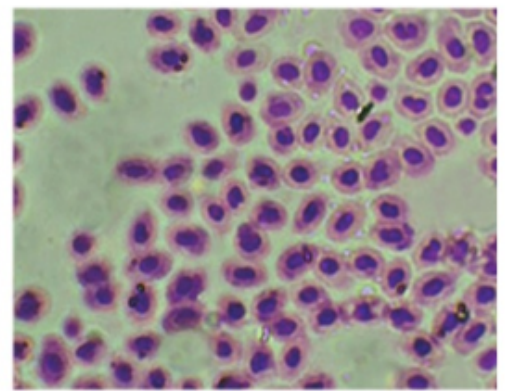

Imid $17.5 \mathrm{ppm}$

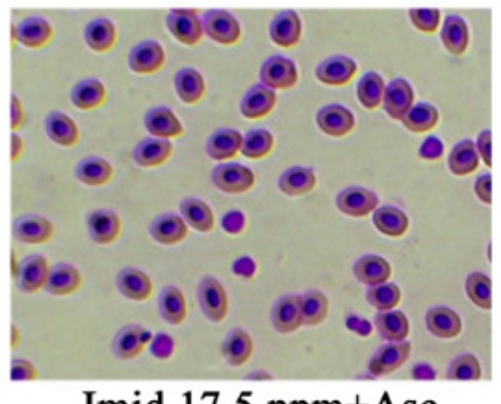

Imid 17.5 ppm+Asc

\section{Figure 5}

Representative micro-photographs of micronuclei (MN) and erythrocytic nuclear abnormalities (ENA) in 0. niloticus, stained with hematoxylin and eosin. The protective effect of ascorbic acid (Asc, $50 \mathrm{ppm}$ ) against the alterations induced by imidacloprid (Imid) concentrations ( $8.75 \& 17.5 \mathrm{ppm}$ ) for 21 days. Values were expressed as mean \pm standard deviation (SD), bars refer to SD, $(n=5$ fish). a indicates 
significant difference respecting the control group ( $\mathrm{p} \otimes 0.05$ ), *, \# indicates significant difference between co-treatment and corresponding Imid-exposed (17.5\& $8.75 \mathrm{ppm})$ groups respectively $(\mathrm{p} \otimes 0.05)$.

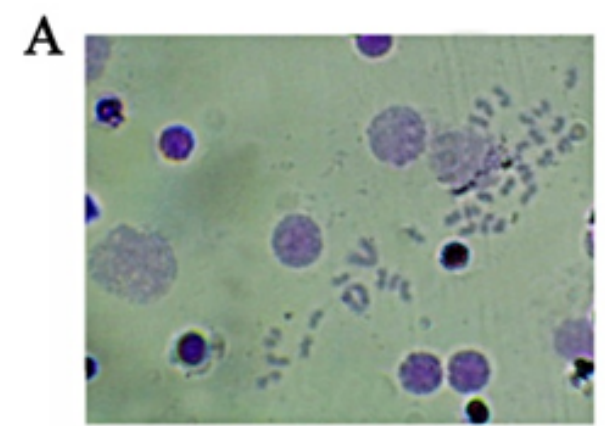

Control

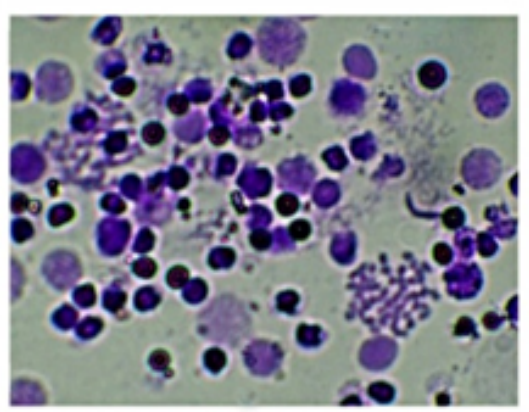

Imid $8.75 \mathrm{ppm}$

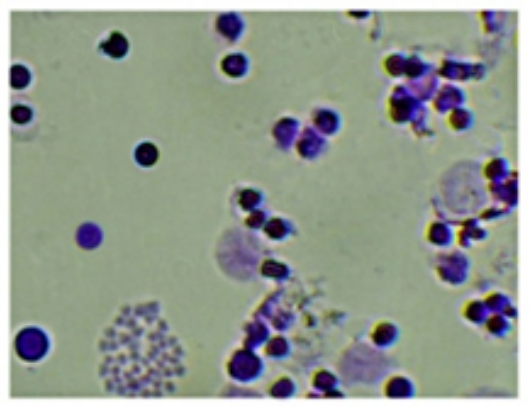

Imid $17.5 \mathrm{ppm}$

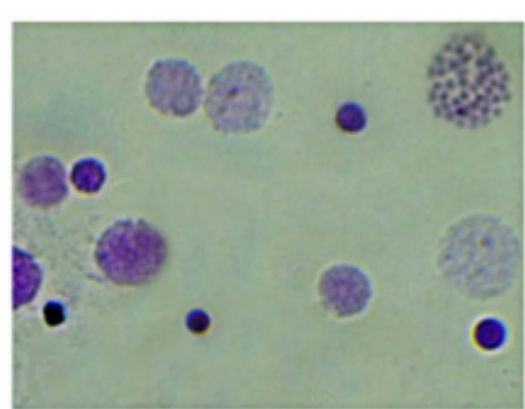

Asc

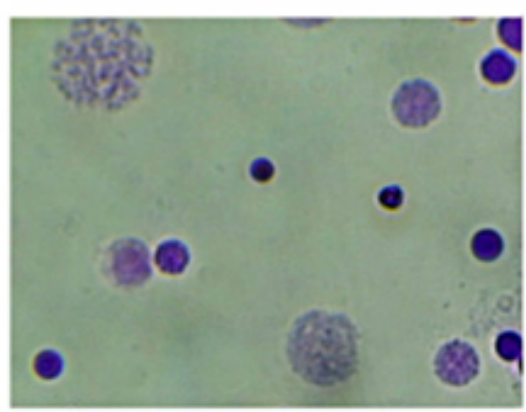

Imid $17.5 \mathrm{ppm}+$ Asc

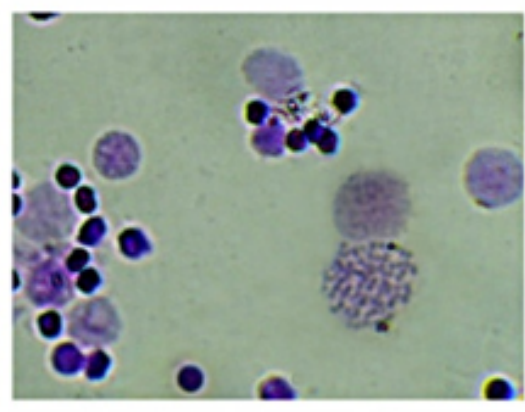

Imid $17.5 \mathrm{ppm}+\mathrm{Asc}$
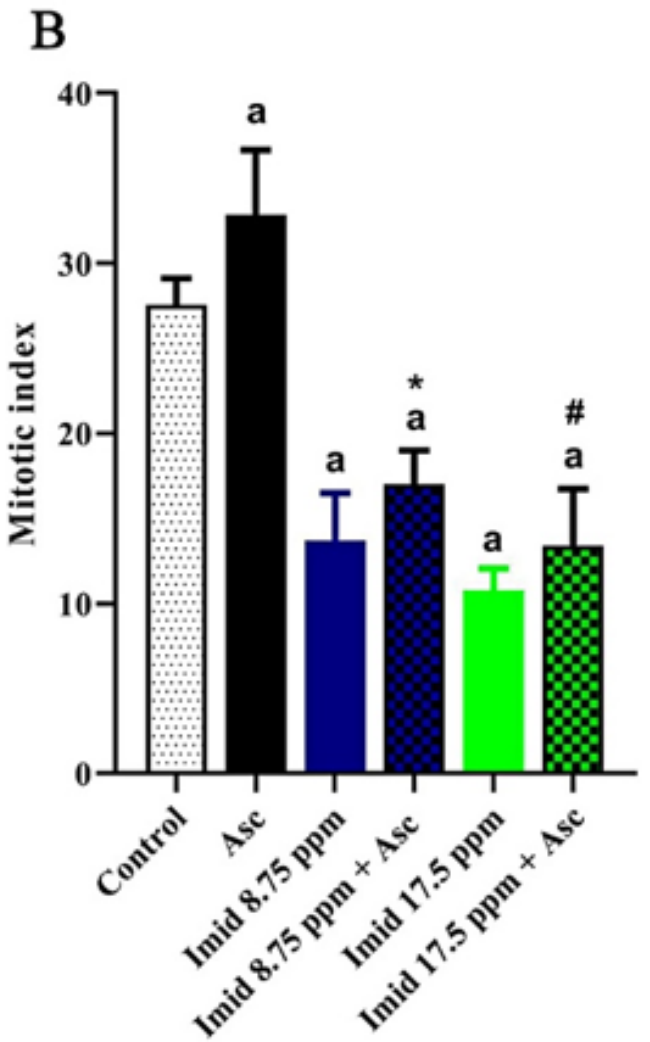

$10 \mu \mathrm{m}$

\section{Figure 6}

The protective effect of ascorbic acid (Asc, $50 \mathrm{ppm}$ ) on the mitotic index changes induced by imidacloprid (Imid) (8.75 \& $17.5 \mathrm{ppm}$ ) applied for 21 days in 0. niloticus. A, representative Representative micro-photographs of studied groups, $B$, the mean values $(M \pm S D)$. Values were expressed as mean \pm standard deviation (SD), bars refer to SD, ( $\mathrm{n}=5 \mathrm{fish}$ ), a indicates significant difference compared to control group ( $\mathrm{p} \otimes 0.05$ ), *, \# indicates significant difference between co-treatment and corresponding Imidexposed (17.5 \& $8.75 \mathrm{ppm})$ groups respectively $(\mathrm{p} \otimes 0.05)$. 